\title{
FUNDAMENTAL DIFFERENCES BETWEEN NATURAL ANTIBODIES AND POLYREACTIVE IMMUNOGLOBULINS
}

\author{
S. A. BOBROVNIK, M. A. DEMCHENKO, S. V. KOMISARENKO \\ Palladin Institute of Biochemistry, National Academy of Sciences of Ukraine, Kyiv; \\ e-mail: s-bobrov@bk.ru
}

A problem of similarity and differences between so-called polyreactive immunoglobulins (PRIGs) and natural antibodies (NAbs), capable of cross-reacting with some structurally dissimilar antigens, has been considered. The analysis of mechanisms of an unspecific interaction between PRIGs or NAbs and antigens evidences for the fact that essential differences exist between these substances. These differences permit classifying the abovementioned substances as different types of immunoglobulin molecules. The major difference between PRIGs and NAbs may include both the mechanisms of the above mentioned immunoglobulin molecules binding to antigens and their interaction affinity, as well as an absolutely different influence of some low-molecular substances on the efficiency of the interaction with antigens. Relying on the obtained data it can be assumed that, since PRIGs and NAbs have fundamental differences, they may perform not only similar but also different functions of the immune system.

Key words: specific antibodies, polyreactive immunoglobulins, antigens, antigen-antibody interaction.

$\mathrm{T}$ he discovery of PRIGs, capable of unspecific binding to various antigens [1], has raised a lot of questions. What is the mechanism of this interaction? Are PRIGs just a result of experimental effects on specific monoclonal or polyclonal serum antibodies or are they present in the intact animal and human sera? What may be the biological role of PRIGs? That was one of the main questions: were the obtained PRIGs identical to so-called NAbs, which had been known and well-studied before [2-6], or PRIGs are a separate subpopulation of immunoglobulins existing in vivo and performing their special functions? To answer these questions we had to perform a lot of different experiments, most of them were connected with interaction between PRIGs and antigens.

Based on the previously obtained results, as well as on some new data presented in this paper, we have concluded that PRIGs differ from NAbs by a whole number of properties. It was also shown that PRIGs are available in the intact human and animal sera in considerable amounts, and that their concentration is increasing with age. Based on the data on PRIGs properties, we supposed fundamental differences between PRIGs and Nabs, as well as identified the functional role of PRIGs and their effect on the course of some diseases.

\section{Materials and Methods}

Human serum albumin (HSA), ovalbumin and horse myoglobin were used in this work as antigens. These reagents were commercial products of the Sigma company, USA. Ovalbumin-specific monoclonal antibodies (mAbs), which also were the product of the Sigma company, USA, or murine serum antibodies twice immunized with ovalbumin were used in the study as specific antibodies. Ortho-phenylenediamine produced by the Sigma company, USA, and hydrogen peroxide produced by Ternofarm, Ukraine, were used as the substrate for enzyme-linked immunosorbent assay (ELISA).

Antigens were immobilized on 96-well polystyrene plates produced by Dunatech Company by two different methods, depending on whether the plates were intended for investigation of mAbs and specific serum antibodies, or nonspecific PRIGs. To study the interaction between specific antibodies or mAbs and ovalbumin, the plates were covered with ovalbumin by the traditional method, i.e., by incubation of ovalbumin solution (concentration 10-15 $\mu \mathrm{g} /$ $\mathrm{ml}$ in $0.15 \mathrm{M}$ phosphate buffer, at $\mathrm{pH}$ 8.5-9.0) in the wells of the plates during $24 \mathrm{~h}$ at $4{ }^{\circ} \mathrm{C}$ with further thorough rinsing of plates from unbound antigen immediately before the experiment. 
To study nonspecific PRIGs binding to antigens, we covered the plate using the previously developed method [7], where the antigen solution $(2.0-3.0 \mu \mathrm{g} / \mathrm{ml})$ in $1 \% \mathrm{NH}_{4} \mathrm{HCO}_{3}$ was dried on the plates at $37^{\circ} \mathrm{C}$. We have demonstrated before that such a method of antigens adsorption on the plate, firstly, raises the adsorption efficiency (compared to traditional incubation of the antigen solution), that allows us to use by the order of magnitude less antigen concentrations [7]. Secondly, our method of the antigen adsorption by drying leads to a more expressed denaturation of adsorbed antigens than under the adsorption by traditional method. The latter may be a disadvantage if investigate specific binding of antibodies, but it serves as a positive factor for studying PRIGs binding possessing a higher affinity for denaturated proteins.

The proper diluted samples of the studied sera or monoclonal antibodies were placed to the plate covered with antigens, the plates were incubated during one hour at $25^{\circ} \mathrm{C}$, washed off thoroughly from the unbound antibodies by running water, after that goat anti-IgG antibodies conjugated with horse radish peroxidase were added, and the quantity of immunoglobulins bound to the antigen was determined by ELISA. As a substrate for peroxidase, we used a mixture of orthophenylene diamine $(1 \mathrm{mg} /$ $\mathrm{ml}$ ) and $0.003 \% \mathrm{H}_{2} \mathrm{O}_{2}$. After color development of the mentioned substrate, the reaction was stopped by adding $0.06 \mathrm{ml}$ of $2.0 \mathrm{M}$ sulfuric acid to each well, and then the optical density of the plate wells was measured by ELx800, BIO-TEK microphotocalorimeter, at $490 \mathrm{~nm}$ wavelength.

\section{Results and Discussion}

It would be reasonable to remind that according to the definition, NAbs are the antibodies produced by human or animal organisms themselves, without any artificial immunization of the organism by one or another antigen. In this connection, it is evident that the antibodies specific to antigens of some infections which the organism suffered from, may occur among NAbs. At the same time, it is known that NAbs are primarily cross-reacting and low-specific antibodies, that makes them similar (to some extent) to serum PRIGs, which we have found.

We first detected the phenomenon of the increasing of human and animal serum immunoglobulins nonspecific reactivity, when treating these sera or their immunoglobulin fractions by KSCN solutions (3.0-5.0 M) or after their acidification to $\mathrm{pH}<3.0$ and further neutralization [1]. The sera treated in such a way changed dramatically their immunochemical properties, since immunoglobulins gained a capacity of binding to antigens adsorbed on microplates many times more intensively as compared to initial intact immunoglobulins, and it might be detected easily using ELISA or some other methods.

One of the major questions, which appeared after we had detected the above phenomenon, was the question whether the obtained PRIGs were identical to the already known low-specific NAbs [2-4], which possessed cross-reactivity to some structurally dissimilar antigens, or PRIGs were similar but new substances not described in literature so far. We repeat that the question appears because some NAbs, like PRIGs, are capable of cross-reactivity with various antigens, which are explicitly different in structure and are identified by specific antibodies as serologically unallied ones.

It should be noted that we have partially answered the question about similarity and differences between NAbs and PRIGs in our first published papers [1]. The point is that the cross-reacting NAbs are the antibodies which are partially specific, and thus they react differently with structurally dissimilar antigens. For this reason, as a rule, a certain soluble antigen A suppresses much more strongly the binding of NAbs to precisely the same antigen A, that covered microplates, than to another serologically unallied antigen B. But we have shown that there are no such regularities in respect of PRIGs, and practically any soluble antigen $\mathrm{X}$ prevents the binding of PRIGs almost in the same way both to the same antigen $\mathrm{X}$ immobilized on the plate, and to the other structurally dissimilar antigens $\mathrm{Y}, \mathrm{Z}$, etc. (Fig. 1).

Moreover, we have shown that PRIG, eluted from the column, where, e.g., a certain antigen A was immobilized, can bind not only to the same antigen $\mathrm{A}$, but also to other serologically unallied antigens B, C, etc., and with the same efficiency as to antigen A (Fig. 2). Thus, while interaction of NAbs with antigens is partially specific, the binding of PRIGs to different antigens is completely unspecific. Nevertheless in our opinion, these distinctions between PRIGs and NAbs were insufficient to state with confidence that they are radically different as to their immunochemical properties, and probably, as to performed functions.

To establish reliably the substantial differences between the interaction of partially specific 

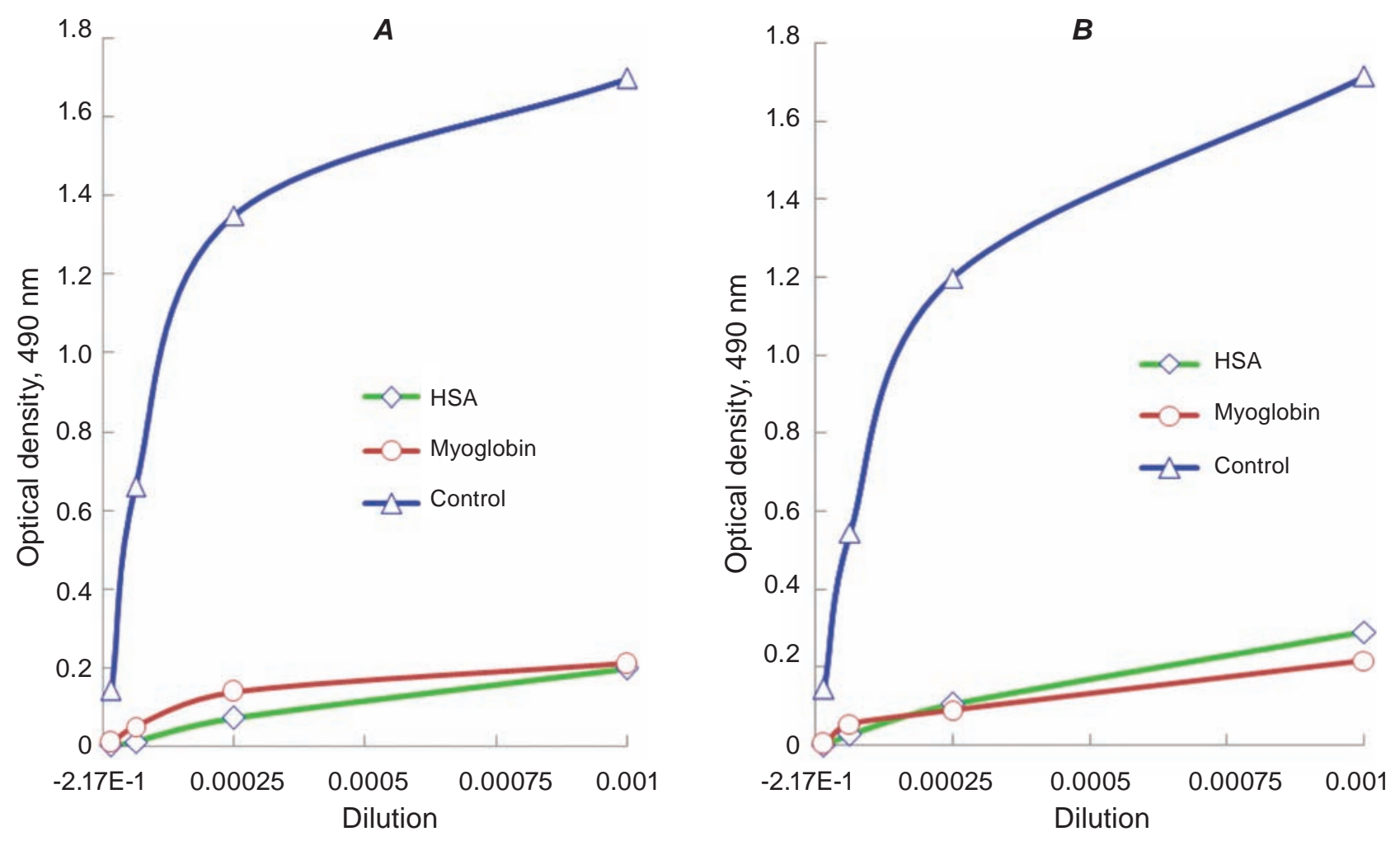

Fig. 1. Estimate of blocking intensity of mouse serum PRIG by soluble antigens (4 mg/ml) - by human serum albumin (HSA) or horse myoglobin (blocking agents were absent in the control). The following antigens were adsorbed on plates for detecting PRIG activity by means of ELISA: A - human serum albumin; B - horse myoglobin. Independent of which antigen was in the solution and which was adsorbed on the plate, the studied PRIG of mouse serum was blocked with approximately similar efficiency
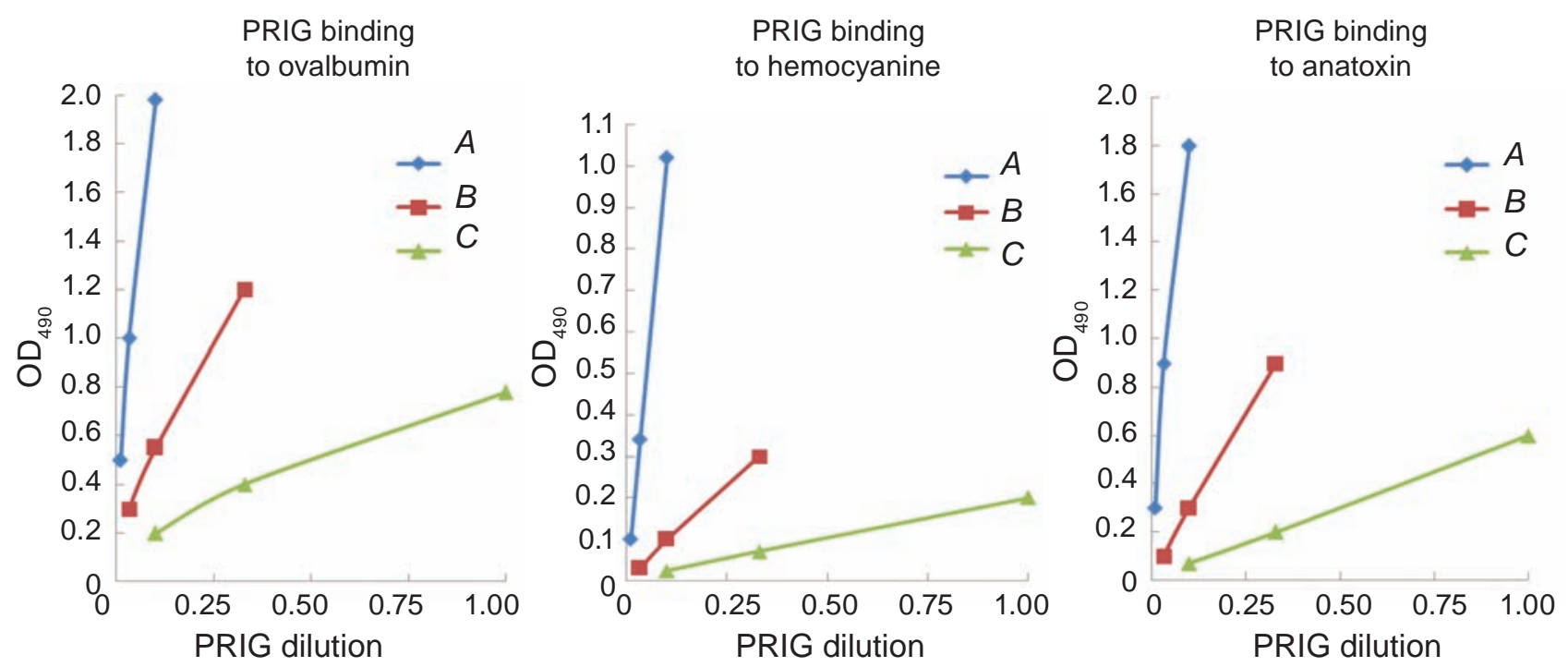

Fig. 2. PRIG binding to ovalbumin, keyhole limpet hemocyanine and staphylococcus anatoxin immobilized on plates. A - initial PRIG sample; B - PRIG sample eluted from the column with immobilized keyhole limpet hemocyanine; $C$ - PRIG sample eluted from the column with immobilized staphylococcus anatoxin 
antibodies with antigens and PRIGs interaction, we have made a number of other tests, and their results are presented below. Firstly, we have found that the temperature affects differently the binding of specific antibodies and unspecific antibodies to antigens (Fig. 3). As it can be seen from the figure, the temperature rise from $4{ }^{\circ} \mathrm{C}$ to $37{ }^{\circ} \mathrm{C}$ takes an inconsiderable effect on the interaction of ovalbumin-specific antibodies with antigen, but it exerts a great effect on PRIGs binding to the same antigen. It may be supposed that the above temperature rise accelerates the binding of specific antibodies to antigen inconsiderably (about 15-20\%), probably mainly through the intensification of the Brownian movement of reacting molecules. In contrast, the temperature rise from $4{ }^{\circ} \mathrm{C}$ to $37^{\circ} \mathrm{C}$ accelerates the binding of PRIGs to antigens 5-10 times, i.e., temperature is one of the most important factors for putting on the mechanism of PRIGs binding to antigens. But it was absolutely unclear: what was the character of the interaction mechanism of PRIGs binding to antigens and why was temperature so important for it.

Later we have found that there are several lowmolecular substances which have different effect on the unspecific binding of PRIGs and on specific interaction of antibodies with the corresponding antigens [8]. Thus, it was established that Tween 20 takes almost no effect on the binding of specific antibodies to antigen, but suppress heavily such inter- action of PRIGs (Fig. 4, A). Later it became clear that such an effect of Tween 20 on PRIG binding to antigens is determined by the fact that Tween 20 screens hydrophobic areas at the surface of the both interacting molecules and therefore weakens PRIGs interaction. It is also evident that such a test could be used, if one has to differentiate between PRIGs and specific antibodies.

Another low-molecular reagent, capable of binding to hydrophobic sites of proteins, i.e., 8-amino-1-naphthol-5-sulfoacid (ANS), like Tween 20, is also the inhibitor of PRIGs interaction with various antigens (Fig.4, B). Besides, one more fact, evidencing that PRIGs binds to antigens by hydrophobic interaction, is that transformation of immunoglobulins in PRIGs is accompanied by the increase of the ability of the latter to bind to hydrophobic surfaces, for example, to polysterene plates for ELISA.

And, at last, we have established that PRIGs has a considerably higher affinity for protein antigens, if the latter are preliminarily denaturated by heating. Hence, allowing for the above data, it became clear that in contrast to specific antibodies, which bind to corresponding antigens, owing to mutual complementarity of interacting surfaces and their opposite electrical charges, PRIGs binding to antigens is mainly determined by hydrophobic interaction of the molecules. Note also, that the elucidation of the mechanism of PRIGs binding to antigens allowed us
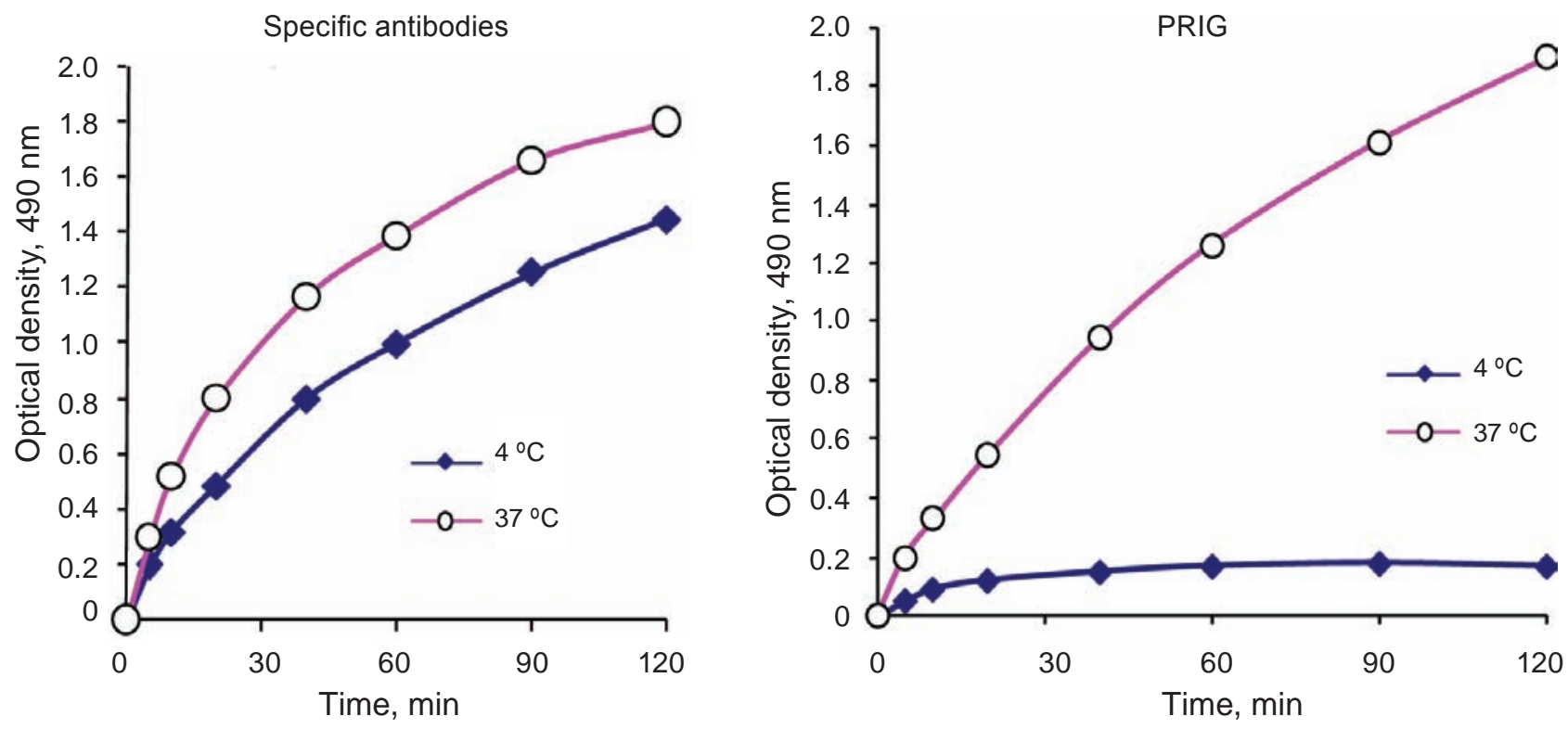

Fig. 3. Effect of temperature elevated from $4{ }^{\circ} \mathrm{C} \partial o 37^{\circ} \mathrm{C}$ on antibodies or PRIG binding to antigen adsorbed on the plate 

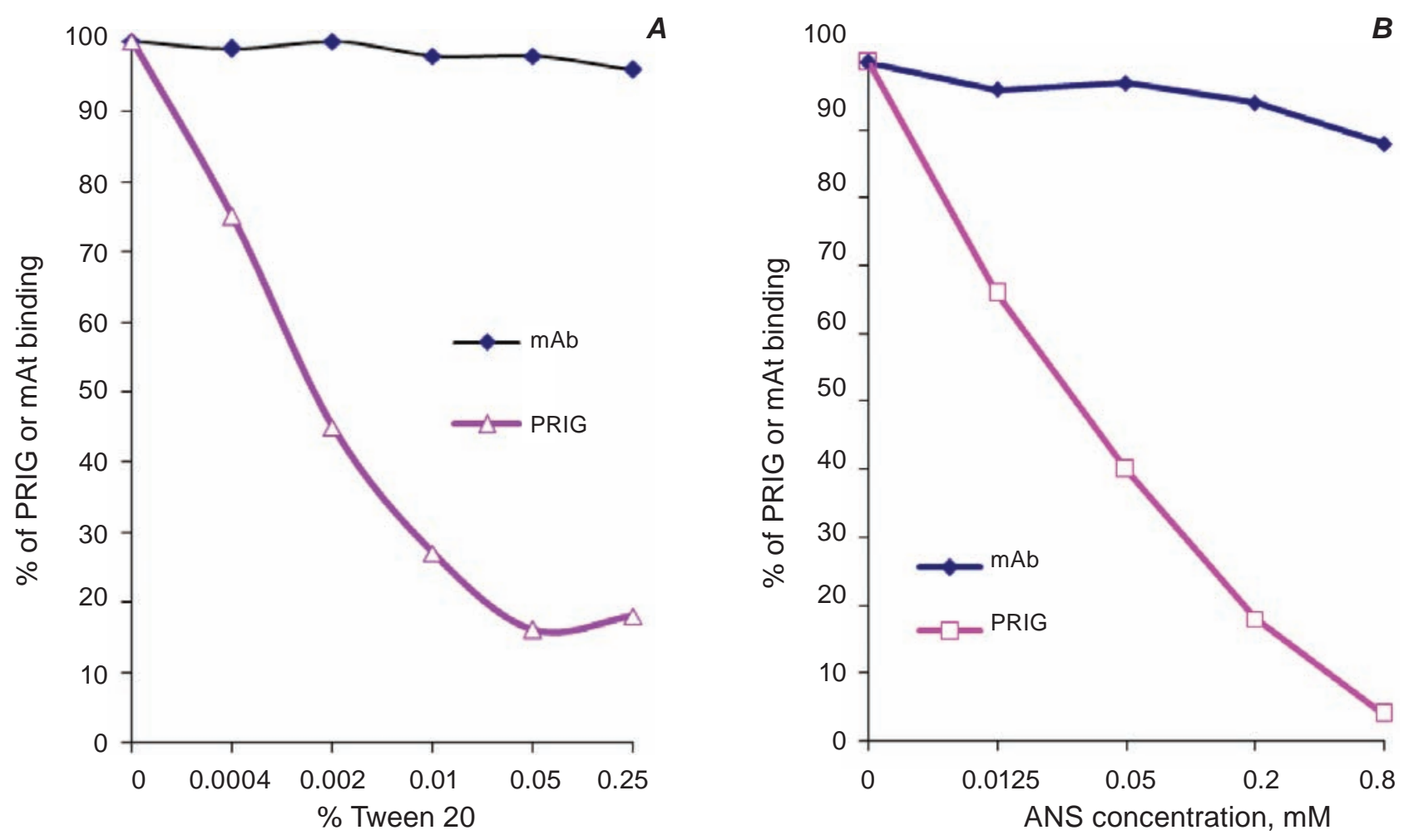

Fig. 4. Supressing of PRIG binding to antigen coupled to the plate with various concentrations of ANS or Tween 20 and the absence of influence of these reagents on binding of specific $m A b$ with the same antigen

to understand why this reaction much more depends on the temperature, in contrast to the binding of specific antibodies to antigens.

In addition, the main PRIGs property distinguishing them from low-specific NAbs is, as it appeared, the value of affinity (or avidity) of their interaction with antigens. We hitherto supposed that PRIGs bind to antigens with very low avidity, as it was demonstrated with low-affine NAbs. At the same time, it seemed that the experimental results also confirmed this stating, since the estimate of PRIGs affinity measured by traditional approaches really showed very low values of the equilibrium constant [9]. However, our revealing of the mechanism of PRIGs interaction with antigens caused the doubts, whether the traditional methods of estimating the affinity of antibodies also suited for the estimation of PRIGs affinity. Moreover, the analysis of the mechanism of PRIGs interaction with antigens indicates that the methods mainly used for estimating the affinity of specific antibodies for the corresponding antigens $[10,11]$ are really unsuitable for estimating the affinity of unspecific binding of PRIGs to antigens. Consequently, PRIGs affinity may be much higher, than it was shown by measuring with the use of such methods and than it was thought before.

Our further experiments confirmed this conclusion and permitted us to establish that the avidity of PRIGs interaction with antigens is not lower than that of highly specific antibodies, and therefore it is hundreds or thousands of times higher than binding avidity of NAbs [12]. One more difference between NAbs and PRIGs is an inability of PRIGs to agglutinate bacterial cells or other corpuscular antigens in contrast to NAbs that can do it very efficiently. Unfortunately, we cannot explain the reason of such differences between NAbs and PRIGs till now. Summarizing the facts presented above we can conclude that low-specific NAbs and unspecific PRIGs are not one and the same biological substance, because these substances have not only some similarity but also have fundamental differences.

Owing to these differences, NAbs and PRIGs may be identified with the use of the tests mentioned above. In addition, it may also be noted that earlier we have already proposed some tests which allowed distinguishing PRIG and specific antibodies [12]. However, the data presented in this article permit us 
Immunochemical properties of specific antibodies and PRIGs

\begin{tabular}{lcc}
\hline \multicolumn{1}{c|}{$\begin{array}{c}\text { Characteristic of the process } \\
\text { of binding to antigens }\end{array}$} & Specific antibodies & PRIG \\
\hline Specificity & yes & no \\
Temperature dependence & low & high \\
Effect of Tween 20 & low & suppresses \\
Effect of ANS & low & suppresses \\
Effect of lysozyme & no effect & stimulates \\
Effect of protamine & no effect & stimulates \\
Interaction avidity & low & high \\
Agglutination of microbes & yes & no \\
Opsonization of microbes & yes & yes \\
Binding of Staphylococcal Protein A & yes & yes \\
Complement binding & yes & yes \\
\hline
\end{tabular}

to do it more efficiently. In addition, these data allow us to make a conclusion concerning the existence of considerable differences between NAbs and PRIGs.

Nevertheless, it should be also noted that NAbs and PRIGs have a number of similar properties. As we have shown before, PRIGs like NAbs can opsonize bacterial cells, favoring their phagocytosis by the cells of reticulo-endothelial system. This fact demonstrates that under the transformation of specific antibodies into PRIGs there mainly occur the changes of Fab-sites of immunoglobulins responsible for the binding to antigens, while Fc-domain preserves its capacity of binding to phagocyte Fcreceptors.

In the same way, PRIGs have the ability to fix serum complement and Staphylococcal Protein A that also evidences for preserving the conformation of the corresponding binding sites, located on the Fc-domain of immunoglobulins. Consequently, we can conclude that in the case of transformation of specific antibodies into PRIGs one can observe changes of the binding properties only in Fab-sites of immunoglobulins, while the structural properties of Fc-domains mainly remain unchanged.

Summing up the above data, we can state that NAbs and PRIGs have a number of properties, which help to distinguish them from each other, and these properties are connected to a peculiar change (and, evidently, conformation) of the immunoglobulins's site responsible for the binding to antigens, namely, to Fab-sites. At the same time, the effector proper- ties and functions of specific antibodies and PRIGs, the Fc-domain of immunoglobulins responsible for them, are relatively stable, they do not change under antibodies transformation in PRIGs and, therefore, they are rather similar in these molecules (Table). Thus, from the data presented in the Table, it follows that the effectors molecule properties, which depend on Fc-domain (such as opsonization of microbes, Staphylococcal Protein A binding, as well as complement binding), are similar in PRIGs and in specific antibodies. On the other hand, the mechanisms of low-specific antibodies and PRIGs binding to antigens, which depend on Fv-domains of the given molecules, have essential differences.

Since NAbs are relatively specific antibodies, though they possess low specificity and are able to cross-react with some structurally dissimilar antigens, the above differences permit us to make a conclusion that PRIGs and NAbs are different substances. These differences allow us not only to discriminate between NAbs and PRIGs with the help of the corresponding tests, but also to suppose that NAbs and PRIGs can probably perform different biological functions in the organism. For example, since PRIGs possess the increased affinity for denaturated protein molecules, it can be assumed that the elimination of the injured macromolecules from the blood flow is one of the basic functions of PRIGs. It may be suggested that in some cases PRIGs can take part in the suppression of the immune response. Our data that PRIGs can favor the acceleration of 
development of the malignant tumor Ehrlich carcinoma, tell about such a possibility, as we have shown it before [13].

So, the data presented evidence that NAbs and PRIGs have essential immunochemical differences and thus may be considered as different substances, which probably perform not only similar but also different biological functions.

\section{ФУНДАМЕНТАЛЬНІ ВІДМІННОСТІ МІЖ НОРМАЛЬНИМИ АНТИТІЛАМИ ТА ПОЛІРЕАКТИВНИМИ ІМУНОГЛОБУЛІНАМИ}

\section{С. А. Бобровник, М. О. Демченко, \\ С. В. Комісаренко}

Інститут біохімії ім. О. В. Палладіна НАН України, Київ; e-mail: s-bobrov@bk.ru

Розглянуто проблему схожості і відмінностей між натуральними антитілами (НАт) та поліреактивними імуноглобулінами (ПРІГ), які здатні перехресно взаємодіяти 3 деякими неспорідненими антигенами. Аналіз механізмів неспецифічної взаємодії 3 антигенами ПРІГ та НАт свідчить про те, що між цими субстанціями є суттєві відмінності, які дозволяють класифікувати ці субстанції як різні типи імуноглобулінових молекул. До основних відмінностей між ПРІГ і НАт можна віднести як механізми зв'язування вказаних імуноглобулінових молекул 3 антигенами, так і афінність цього зв'язування, а також зовсім відмінний вплив деяких низькомолекулярних речовин на ефективність їх взаємодії 3 антигенами. На основі одержаних даних можна припустити, що оскільки ПРІГ та НАт принципово відрізняються за властивостями, то вони, мабуть, виконують не тільки схожі, а й відмінні функції імунної системи.

К л ю чо в і с л о в а: специфічні антитіла; поліреактивні імуноглобуліни; антигени; взаємодія антиген-антитіло.

\section{ФУНДАМЕНТАЛЬНЫЕ \\ РАЗЛИЧИЯ МЕЖДУ \\ НОРМАЛЬНЫМИ АНТИТЕЛАМИ \\ И ПОЛИРЕАКТИВНЫМИ ИММУНОГЛОБУЛИНАМИ}

\author{
С. А. Бобровник, М. А. Демченко, \\ С. В. Комисаренко
}
Институт биохимии им. А. В. Палладина НАН Украины, Киев; e-mail: s-bobrov@bk.ru

Рассмотрена проблема сходства и различий между так называемыми полиреактивными иммуноглобулинами (ПРИГ) и натуральными антителами (НАт), способными перекрёстно реагировать с некоторыми неродственными антигенами. Анализ механизмов неспецифического взаимодействия с антигенами ПРИГ и НАт свидетельствует о том, что между этими субстанциями имеются существенные различия, которые позволяют классифицировать данные субстанции как разные типы иммуноглобулиновых молекул. К основным различиям между ПРИГ и НАт можно отнести как механизмы связывания указанных иммуноглобулиновых молекул с антигенами, так и аффинность этого взаимодействия, а также совершенно различное влияние некоторых низкомолекулярных веществ на эффективность взаимодействия с антигенами. На основании полученных данных можно предположить, что поскольку свойства ПРИГ и НАт имеют принципиальные различия то, по-видимому, они выполняют не только сходные, но и различные функции иммунной системы.

К л ю че в ы е с л о в а: специфичные антитела; полиреактивные иммуноглобулины; антигены; взаимодействие антиген-антитело.

\section{References}

1. Bobrovnik S. A. Activation of "silent" antibodies and their interaction with antigens. Ukr. Biokhim. Zhurn. 1990;62(5):86-89. (In Russian). 
2. Avrameas S., Guilbert B., Dighiero G. Natural antibodies against tubulin, actin myoglobin, thyroglobulin, fetuin, albumin and transferrin are present in normal human sera, and monoclonal immunoglobulins from multiple myeloma and Waldenström's macroglobulinemia may express similar antibody specificities. Ann. Immunol. (Paris). 1981;132C(2):231-236.

3. Guilbert B., Dighiero G., Avrameas S. Naturally occurring antibodies against nine common antigens in human sera. I. Detection, isolation and characterization. J. Immunol. 1982;128(6):27792787.

4. Dighiero G., Guilbert B., Avrameas S. Naturally occurring antibodies against nine common antigens in humans sera. II. High incidence of monoclonal Ig exhibiting antibody activity against actin and tubulin and sharing antibody specificities with natural antibodies. J. Immunol. 1982;128(6):2788-2792.

5. Avrameas S. Natural autoantibodies: from 'horror autotoxicus' to 'gnothi seauton'. Immunol. Today. 1991;12(5):154-159.

6. Avrameas S., Ternynck T. The natural autoantibodies system: between hypotheses and facts. Mol. Immunol. 1993;30(12):1133-1142.

7. Bobrovnik S. A., Starodub N. F. A new simple method of antigen immobilization on immunological plates. Immunology (Mosc.). 1988;(5):83-85. (in Russian).
8. Bobrovnik S. A. Polyreactive immunoglobulins recognize hydrophobic parts of proteins. Ukr. Biokhim. Zhurn. 2001;73(2):116-122.(In Russian).

9. Bobrovnik S. A. Polyreactive immunoglobulins: molecular properties and functions. Comments Mol. Cell. Biophys. 1999;9:323-356.

10. Friguet B., Chaffotte A. F., Djavadi-Ohaniance L., Goldberg M. E. Measurements of the true affinity constant in solution of antigen-antibody complexes by enzyme-linked immunosorbent assay. J. Immunol. Methods. 1985;77(2):305-319.

11. Stevens F. J. Modification of an ELISA-based procedure for affinity determination: correction necessary for use with bivalent antibody. Mol. Immunol. 1987;24(10):1055-1060.

12. BobrovnikS. A. Avidity of polyreactive immunoglobulins. Ukr. Biochem. J. 2014;86(6):183-189. (In Russian).

13. Bobrovnik S. A., Lavrenchuk G. I., Benkovska N. P., Chornaya N. E. Influence of polyreactive immunoglobulins on tumor cells prolipheration. Exp. Oncology. 1998;(20):202207. (In Russian). 